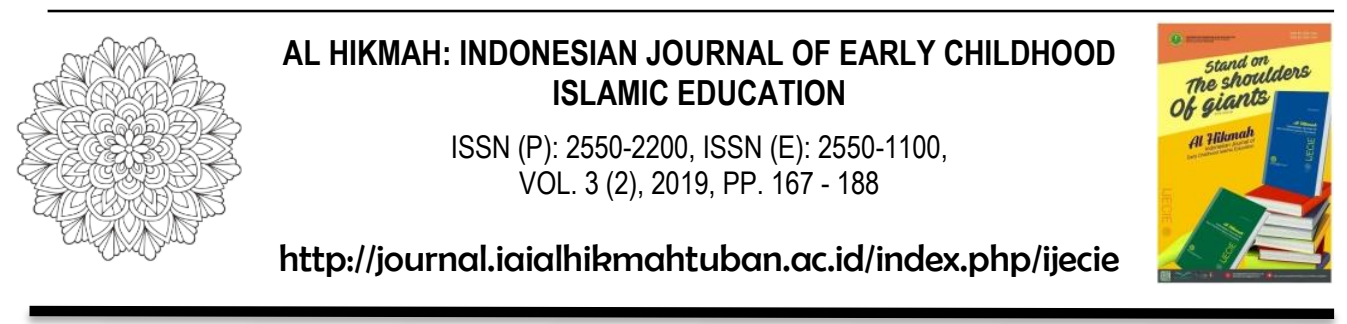

\title{
STRATEGI PENDAMPINGAN ORANG TUA TERHADAP INTENSITAS PENGGUNAAN GADGET PADA ANAK
}

\author{
Nurul Novitasari \\ Prodi Pendidikan Islam Anak Usia Dini, STAI Al Hikmah Tuban \\ nurul.novita_sari@yahoo.com
}

\section{Abstrak}

Perkembangan gadget sangat berpengaruh dalam perkembangan kehidupan manusia. Fenomena ini paling mudah ditemui pada anak yang berasal dari keluarga berada dimana gadget bukan lagi menjadi barang mewah bagi mereka. Dampak negatif penggunaan gadget pada anak antara lain: 1) menjadi pribadi tertutup, 2) kesehatan otak terganggu, 3) kesehatan mata terganggu, 4) kesehatan tangan terganggu, 5) gangguan tidur, 6) suka menyendiri, 7) perilaku kekerasan, 8) pudarnya kreativitas, 9) terpapar radiasi, dan 10) ancaman cyberbullying. Orang tua memiliki peran besar dalam membimbing dan mencegah agar teknologi gadget tidak berdampak negatif bagi anak. Cara-cara yang harus dilakukan oleh orang tua ialah sebagai berikut: 1) pilih sesuai dengan usia anak, 2) Selektif dalam memilihkan aplikasi permainan di dalam gadget, 3) Temani anak dalam bermain, 4) Batasi waktu bermain gadget anak, dan 5) Mengajak anak melakukan kegiatan positif.

Kata Kunci: Pendampingan Orang Tua, Penggunaan Gadget, Anak

\begin{abstract}
The development of gadgets is very influential in the development of human life. This phenomenon is most easily found in children who come from families where gadgets are no longer a luxury item for them. The impact of the use of gadgets on children include: 1) being private closed, 2) impaired brain health, 3) impaired eye health, 4) impaired hand health, 5) sleep disturbances, 6) aloofness, 7) violent behavior, 8) fading creativity, 9) radiation exposure, and 10) cyberbullying threats. The parents have a big role in guiding and preventing gadget technology from having a negative impact on children. Ways that must be done by parents are as follows: 1) select according to the age of the child, 2) Be selective in choosing the game application in the gadget, 3) Accompany children in playing, 4) Limit the time playing gadget for children, and 5) Invite children to do positive activities.
\end{abstract}

Keywords: Parent assistance, Gadget Usage, Child 


\section{PENDAHULUAN}

Perkembangan yang menonjol pada era modern seperti saat ini yakni dari sisi teknologi yang terus dan akan semakin berkembang sesuai dengan berkembangnya kebutuhan dan keinginan manusia yang tidak aka nada habisnya untuk dipenuhi. Salah atu wujud dari perkembangan teknologi adalah dengan adanya gadget yang sudah tersedia dimana-mana baik dalam bentuk laptop, computer, smartphone, televisi, radio, game dan lain sebaginya. Gadget sangat mudah sekali menarik perhatian dan minat anak dan sudah menjadi hal yang biasa jika anak-anak saja sudah memakai gadget dalam kehidupan sehari-hari. Gadget memiliki dampak positif dan negatif.

Berdasarkan hasil penelitian yang dilakukan oleh The Asian Parent Insight pada November 2014, sebanyak 98\% dari 2.714 orang tua di Asia Tenggara yang mengikuti penelitian ini mengizinkan anaknya untuk mengakses teknologi berupa computer, smartphone atau tablet. Penelitian ini dilakukan terhadap 2.714 orang tua di Asia Tenggara yang memiliki anak berusia 3-8 tahun. Para orang tua peserta penelitian ini berasal dari Singapura, Malaysia, Thailand, Indonesia dan Filipina. Dari hasil survey tersebut kebnyakan orang tua memperbolehkan anaknya bermain gadget untuk tujuan edukasi. Namun kenyataannya menurut hasil survey sebagian besar putra putri mereka menggunakan gadget tersebut untuk tujuan hiburan seperti game (Unantenne, 2014)

Penggunaan gadget saat ini bukan hanya kalangan orang dewasa maupun remaja saja, anak-anak yang masih duduk di playgroup kini sudah tidak asing dengan yang namanya gadget. Orang tua pun akhirnya sudah bnyak yang memberikan gadget kepada anak. Tanpa disadari oleh orang tua, banyak anak yang sudah kecanduan gadget. Hal tersebut masih di anggap sepele oleh orang tua, sebab orang tua menganggap bahwa sekarang adalah era digital yaitu zaman memakai gadget. Kalau belum memakai gadget 
berarti masih ketinggalan zaman. Orang tua belum mengerti bahwa kecanduan gadget sangat berbahaya bagi anak sebab kecanduan gadget dapat mengganggu psikis dan fisik anak.

Kini waktu yang dihabiskan anak-anak dengan media setiap harinya lebih bnyak. Waktu yang dihabiskan untuk menonton televisi rata-rata 3 jam di hari sekolah dan 7.4 jam pada hari libur, waktu bermain permainan elektronik 3.8 jam dan waktu dihabiskan untuk bermain internet rata-rata 2.1 jam. Maraknya pengguna gadget pada anak tidak lepas dengan adanya pendampingan orang tua terhadap intensitas pengguaan gadget pada anak. Dalam hal ini orang tua memiliki strategi pendampingan yang sangat penting dalam membimbing, mengajarkan, menentukan perilaku dan cara pandang anak, khususnya pada anak yang menggunakan gadget.

Menurut Brooks (2011) mengungkapkan bahwa orang tua memberikan gadget kepada anak karena beberapa alasan, seperti menenangkan anak saat rewel, membuat anak mudah tidur atau makan, dan memberikan waktu luang bagi orang tua agar dapat melakukn pekerjaan rumah tangga atau bersantai. Namun menurut Shanty (2010) bahwa pola asuh permisif yang digunakan oleh orang tua dalam menghadapi anak temper tantrum cenderung membuat anak akan memberontak atau meletakkan emosinya (temper tantrum) untuk mendapatkan apa yang diinginkan.

Orang tua sebaiknya mendampingi anak dan memberikan araha atau pengawasan dalam menggunakan gadget supaya anak dapat bijak dalam menggunakan gadget. Dengan dampingan dan arahan dari orang tua, secara tidak langsung menjadikan anak lebih terbatas dalam menggunakan gadget serta mengetahui apa yang boleh di akses dan apa yang tidak boleh di akses sesuai dengan usianya, selian dapat mengenalkan nama pengguna gadget yang baik dan orang tua juga dapat mengontrol kecanduan anak terhadap 
penggunaan gadget. Salah satu teori yang dikemukakan oleh John Locke bahwa modelling yang baik sangat mempengaruhi anak, yakni bahwa anakanak mempelajari apa yang mereka lihat dari lingkungan sekitarnya.

\section{PEMBAHASAN}

\section{A. Anak}

Anak adalah investasi dan harapan masa depan bangsa serta sebagai penerus generasi di masa mendatang. Dalam siklus kehidupan, masa anakanak merupakan fase dimana anak mengalami tumbuh kembang yang menentukan masa depannya. Perlu adanya optimalisasi perkembangan anak, karena selain krusial juga pada masa itu anak membutuhkan perhatian dan kasih saying dari orang tua atau keluarga sehingga secara mendasar hak dan kebutuhan anak dapat terpenuhi secara baik.

Usia Dini merupakan periode masa emas bagi perkembangan anak dimana tahap perkembangan otak pada anak udia dini menempati posisi yang paling viral yakni meliputi $80 \%$ perkembangan otak anak (Hibana, 2002). Berdasarkan keunikan dalam pertumbuhan dan perkembangannya, anak usia dini terbagi dalam tiga tahapan, yaitu (1) masa bayilahir sampai 12 bulan, (2) masa toddler (batita) usia 1-3 tahun, (3) masa prasekolah usia 3-6 tahun, (4) masa kelas awal SD 6-8 tahun. Pertumbuhan dan perkembangan anak usia dini perlu diarahkan pada peletakan dasar-dasar yang tepat bagi pertumbuhan dan perkembangan manusia seutuhnya, yaitu pertumbuhan dan perkembangan fisik, daya pikir, daya cipta, sosial meosional, Bahasa dan komunikasi yang seimbang sebagai dasar pembentukan pribadi yang utuh.

\section{B. Pengertian Gadget}

Gadget adalah sebuah perangkat atau instrumen elektronik yang memiliki tujuan dan fungsi praktis terutama untuk membantu pekerjaan 
manusia.perangkat elektronik kecil yang memiliki fungsi khusus. Diantaranya smartphone seperti iphone dan blackberry, serta notebook (perpaduan antara komputer portabel seperti notebook dan internet) (Widiawati, 2016).

Dalam bahasa Indonesia, gadget disebut sebagai "gawai". Istilah gadget sebagai benda dengan karakteristik unik, memiliki sebuah unit dengan kinerja yang tinggi dan berhubungan dengan ukuran serta biaya. Menurut Derry Iswidharmanjaya gadget adalah perangkat atau instrument elektronik yang memiliki tujuan dan fungsi yang praktis terutama untuk membantu pekerjaan manusia.

Gadget merupakan sebuah inovasi dari teknologi terbaru dengan kemampuan yang lebih baik dan fitur terbaru yang memiliki tujuan maupun fungsi lebih praktis dan juga lebih berguna. Seiring perkembangan, pengertian gadget pun menjadi berkembang yang sering kali menganggap smartphone adalah sebuah gadget dan juga teknologi komputer ataupun laptop bila telah diluncurkan produk baru juga dianggap sebagai gadget. Gadget adalah sebuah istilah yang berasal dari bahasa Inggris, yang artinya perangkat elektronik kecil yang memiliki fungsi khusus. Salah satu hal yang membedakan gadget dengan perangkat elektronik lainnya adalah unsur "kebaruan" artinya, dari hari ke hari gadget selalu muncul dengan menyajikan teknologi terbaru yang membuat hidup manusia menjadi lebih praktis. Contoh-contoh dari gadget di antaranya telepon pintar (smartphone) seperti iphone dan blackberry, serta netbook (perpaduan antara komputer portabel seperti notebook dan internet).

Sekarang gadget bukanlah benda yang asing lagi, hampir semua orang memilikinya. Tidak hanya masyarakat perkotaan, gadget juga memiliki oleh masyarakat pedesaan. Sekarang ini meman tiap-tiap dari 
masyarakat baik tua maupun muda dan dari berbagai golongan telah mampu mengoperasikan gadget dengan baik. Bahkan gadget memang cenderung di targetkan kepada anak-anak usia sekolah atau remaja. Mereka sekarang ini sudah sangat akrab sekali dengan teknologi yang satu ini. Dampak positif dan negative gadget terhadap anak.

Pada mulanya gadget memang lebih difokuskan kepada sebuah alat komunikasi, namun semenjak kemajuan jaman alat ini dipercanggih dengan fitur-fitur yang ada di dalamnya sehingga memungkinkan penggunanya untuk melalkukan berbagai kegiatan dengan satu gadget ini, dari bertelepon, berkirim pesan, email, foto dan masih bnyak yang lainnya.

\section{Sejarah Gadget}

Gadget merupakan perangkat elektroni kecil yang memiliki fungsi khusus dan memiliki banyak jenisnya seperti smart phone, laptop, video game, dan tablet $P C$, dll. Berikut sejarah singkat dari masing-masing sebagian jenis gadget:

1. Sejarah singkat Smart Phone.

Smart Phone pertama kali ditemukan pada tahun 1992 oleh IBM di Amerika Serikat, yakni sebuah perusahaan yang memproduksi perangkat elektronik. Tetapi jangan anda kira Smar Phone pada saat itu secanggih seperti saat ini, Smart Phone pertam kali dilengkapi fasilitas kalender, buku telefon, jam dunia, bagian pencatat, email, juga untuk mengirim faks juga permainan. Namun satu hal yang perlu diketahui Smart Phone buatan IBM ini tidak dilengkapi tombol namun telah dilengkapi dengan teknologi layar sentuh atau tauchscreen. Meskipun cara mempencetnya masih menggunakan tongkat stylus. Pada saat ini sudah banyak perusahaan yang mengembangkan Smart Phone hingga populer digunakan yakni sebut saja perusahaan Nokia, Samsung, Blacberry, Motorola, HTC dan masih banyak lagi (Derry, 2014). 
2. Sejarah singkat Laptop

Alan Kay dapat dikatakan sebagai penemu gadget yang disebut dengan nama laptop. Pada tahun 1970 telah merancang komputer portabel, ia adalah seorang ilmuan komputer asal Amerika yang lahir pada tahun 1940. Ia memiliki ide untuk membuat komputer portabel agar memudahkan dalam penggunaannya. Ide ini didukung oleh Adam Osborne yakni seorang penerbit Shoftware dan bekerja disebuah penerbitan buku di Amerika.

Pada tahun 1981 laptop pertama diluncurkan kepasaran dengan nama Osborne. Dari bentuknya mungkin komputer ini tampak aneh karena tabungnya cembung dengan berat hampir 12 kilogram, dan masih menggunakan sambungan listrik meskipun sudah dilengkapi batre cadangan. Namun kini laptop telah mengalami kemajuan pesat dengan berbagai macam fitur pelengkap sehingga memudahkan pemakainya.

3. Sejarah singkat tablet PC

Elisa Grey disebut sebagai penemu perangkat yang kini disebut $P C$ tablet. Perangkat yang dibuat oleh Elisa ini berfungsi untuk mengenali tulisan tangan. Namun alat itu bukan disebut sebagai PC tablet tetapi Teleautograph. Pada tahun 1945 Vennear Bush mengembangkan temuan Elisa dengan perangkat yang diberi nama memex. Namun alat ini begitu besar sebesar meja. Alat ini berfungsi merekam tulisan atau gambar. Mulai tahun 1950 berbagai produsen mulai mengembangkan konsep ini dan hasilnya adalah perangkat tambahan pengenal tulisan. Jadi pada saat itu adalah penemuan pena stylush yang melengkapi komputer. Lambat laun konsep-konsep semacam ini dikembangkan lagi oleh Bill Gates tepatnya diera tahun 2000-an hingga hasilnya adalah Gadget yang disebut PC Tablet atau disingkat menjadi Tablet (Derry, 2014). 
4. Sejarah singkat Vidio Game

Penemu game adalah Steven Russel pada tahun 1962. Ia memproduksi beberapa permainan yang terkenal adalah Starwars. Delapan tahun kenudian, sekitar tahun 1970-an muncul game yang cukup terkenal dikalangan gamers saat itu, namanya Game Pong dengan menggunakan sistem disket atau cartridge. Setelah itu pada tahun 1980-an muncul game yang cukup populer dengan basis tekhnologi IBM PC yakni game patman. Di tahun 1993 tercipta game yang juga tidak kalah populernya dengan patman yakni game Mortal Combat. Game ini mengusung genre aksi dimana dua karakter akan saling beradu jurus dan ilmu untuk saling menjatuhkan. Lima tahun kemudian munculah game Doom dengan desain yang lebih canggih karena tekhnologinya telah menggunakan basis 3D tetapi sederhana dan sistem suara yang masih terbatas. Lalu di tahun 2000an seiring perkembangan tekhnologi maka tampilan game berubah, mulai dari efek suara hingga gambar tampak lebih realistik. Hal ini juga dibarengi perkembangan mesin game atau sering disebut konsul seperti playtation atau $X$-box. Tak cukup itu kini game dapat dimainkan di Gadget lain seperti smartfhone, tablet,ataupun laptop. Bahkan dengan adanya game onlane maka game akan selalu berkembang.

\section{Dampak positif dan Negatif Pengaruh Gadget Terhadap Anak}

Dokter anak asal Amerika Serikat Cris Rowan menegaskan, harus ada pelarangan penggunaan gadget pada anak berusia di bawah 12 tahun. Sebab, tidak sedikit penelitian yang membuktikan, gadget lebih banyak membawa dampak negatif ketimbang manfaat bagi anak. Adapun beberapa dampak positif dari penggunaan gadget, terutama untuk anak-anak di bawah usia dini yakni: 
1. Menambah Pengetahuan

Rizki Syaputra, Dhani. (2013) menyimpulkan bahwa dengan menggunakan gadget yang berteknologi canggih, anak-anak dengan mudah dan cepat untuk mendapatkan informasi mengenai tugas nya disekolah. Misalnya kita ingin browsing internet dimana saja dan kapan saja yang ingin kita ketahui. Dengan demikian dari internet kita bisa menambah ilmu pengetahuan.

2. Memperluas Jaringan Persahabatan

Gadget dapat memperluas jaringan persahabatan karena dapat dengan mudah dan cepat bergabung ke sosial media. Jadi, kita dapat dengan mudah untuk berbagi bersama teman kita.

3. Mempermudah Komunikasi

Gadget merupakan salah satu alat yang memiliki tekonologi yang canggih. Jadi semua orang dapat dengan mudah berkomunikasi dengan orang lain dari seluruh penjuru dunia.

4. Melatih kreativitas anak

Kemajuan teknologi telah menciptakan beragam permainan yang kreatif dan menantang. Banyak anak yang termasuk kategori ADHD diuntungkan oleh permainan ini oleh karena tingkat kreativitas dan tantangan yang tinggi. Menurut Baihaqi dan Sugiarmin (2006: 2) ADHD sendiri merupakan singkatan dari Attention Deficit Hyperactivity Disorder yang merupakan gangguan perkembangan dalam peningkatan aktivitas motorik anak-anak hingga menyebabkan aktivitas anak-anak yang tidak lazim dan cenderung berlebihan.

Sedangkan dampak negative penggunaan gadget pada anak antara lain: 
1. Menjadi pribadi tertutup

Ketika anak telah kecanduan gadget pasti akan menganggap perangkat itu adala bagian hidupnya. Mereka akan merasa cemas bilamana gadget tersebut dijauhkan. Sebagian waktunya akan mengganggu kedekatan dengan orang tua. Lingkungan, bahkan teman sebayanta. Jika dibiarkan saja keadaan akan membuat anak menjadi tertutup atau introvert.

Kegiatan di sekolah hanya dilakukan sekadar kewajiban saja sebab anak yang kecanduan gadget ini akan menganggap perangkat itu sebagai teman setianya. Akan terjadi konflik dalam batinnya ketika ia harus bersosialisasi dengan teman sebaya baik di lingkungan rumah maupun sekolah.

2. Kesehatan otak terganggu

Otak bagian depan seorang anak sebenanrnya berjumlah sempurna seperti layaknya orang yang sudah dewasa. Menurut para ahli kesehatan otak bagian depan seorang individu matang pada usia 25 tahun. Sementara fungsi otak bagian depan adalah pusat memerintahkan tubuh untuk melakukan pergerakan dan reseptornya yang mendukung otak depan adalah otak bagian belakang yang berfungsi menghasilkan hormone dopamine yakni hormone yang menghasilkan perasaan nyaman atau tenang.

Bila anak telah bermain dengan gadget lalu ia membuka informasi yang negative misalkan pornografi atau kekerasan. Maka informasi itu akan terekam dalam memori otak dan sulit untuk dihapus dari pikiran bahkan untuk waktu yang lama. Jika saja hal ini tidak segera diatasi maka anak akan kecanduan karena adanya hormone dopamin yang 
dihasilkan ketika melihat informasi pornografi atau kekerasan membuatnya nyaman.

3. Kesehatan mata terganggu

Sebuah penelitian menunjukkan bahwa ketika individu membaca pesan teks atau browsing di internet melalui smartphone atau tablet cenderung memegang gadget ini lebih dekat dengan mata, sehingga otot-otot pada mata akan cenderung bekerja lebih keras.

Menurut Derry (2014) Kerja mata saat menggunakan gadget adalah memfokuskan dengan teks pada smartphone ataupun table, hal itu jika dibaarkan akan menyebabkan sakit kepala dan tegang di daerah kelopak mata.

4. Kesehatan tangan terganggu

Ketika anak memainkan gadget seperti misalnya video game dengan frekuensi yang tinggi biasanya akan mengalami kecapekan di bagian tangan terutama bagian jari. Penyakit ini disebut oleh ahli kesehatan dengan nama "sidrom vibrasi". Hal tersebut dikarenakan seorang anak memainkan game dengan memakai controller lebih dari tujuh jam.

Teknologi touchscreen memang memudahkan pengguna dalam menggunakan gadget. Tetapi posisi tangan saat penggunaan layer touchscreen akan mempengaruhi kesehatan tangan. Semakin lama pengguna menekuk tangan maka semakin rawan pergelangan cedera.

5. Gangguan tidur

Bagi anak yang kecanduan akan gadget tanpa adanya pengawasan orang tua ia akan selalu memainkan gadget itu. Bila itu dilakukan dan terjadi terus menerus tanpa adanya Batasan waktu maka akan mengganggu jam tidurnya. 
Orang tua membuat kesepakatan dengan anak. Misalnya dengan membuat aturan menonaktifkan smartphone saat menjelang akan tidur. Sebab jika gadget itu menyala akan mengganggu istirahat anak terutama anak yang di bawah usia 13 tahun.

6. Suka menyendiri

Ketika anak sudah merasa asyik bermain dengan gadget-nya makai a akan merasa itu adalah segalanya. Ia tidak peduli lagi dengan apapun yang ada di sekitarnya karena yang dibutuhkan adalah bermain dengan gadget-nya itupun dilakukannya sendiri tanpa siapapun.

Di sekolah ketika anak harus bertemu dengan teman sebaya ia akan sulit berinteraksi ataupun berkomunikasi secara sehat. Sebab konsentrasinya hanyalah kepada gadget yang menyajikan fantasi yang lebih menarik dari pada harus bergaul. Di kehidupan yang nyata ia akan kesulitan untuk focus akhirnya jadilah ia anak yang menyendiri.

7. Perilaku kekerasan

Menurut penelitian perilaku kekerasan yang terjadi pada anak dikarenakan anak sering mengkonsumsi materi kekerasan baik itu melalui game atau media yang menampilkan kekerasan. Beberapa orang tua mengaku tidak mengetahui bahwa game yang diberikan untuk anaknya mengandung unsur kekerasan. Padahal dalam sampul game telah ditampilkan rating sesuai dengan umur pemainnya.

Adapun perilaku kekerasan yang terjadi pada anak karena sebuah proses belajar yang salah dimana proses kebiasaan melihat materi yang berulang-ulang akan mengindikasikan perilaku kekerasan.

8. Pudarnya kreativitas

Dengan adanya gadget, kecenderungan anak menjadi kurang kreatif lagi. Itu dikarenakan ketika ia diberi tugas oleh sekolah ia tinggal 
browsing internet untuk menyelesaikan tugas. Di sisi lain gadget memudahkan seorang anak dalam belajar namun di sisi lain kreativitasnya akan terancam pudar jika ia terlalu menggantungkan dengan perangkat tersebut.

Karena ia tinggal melakukan copy-paste materi yang ada dalam sebuah situs internet. Perlu diketahui dalam perkembangan usia kanakkanak ia sebaiknya menggunakan kreatifitas untuk proses pembelajaran hal ini dikarenakan penting untuk perkembangan di usia selanjutnya.

9. Terpapar radiasi

Sebuah gadget seperti misalkan laptop sebenarnya memancarkan radiasi namun radiasi berfrekuenasi rendah. Efek yang ditimbulkan ketika bermain laptop terlalu lama biasanya mengakibatkan mata berarir karena kelelahan mata.

Tetapi yang saat ini masih menjadi perdebatan yakni penggunaan smartphone ketika digunakan untuk telepon. Beberapa pakar kesehatan mengatakan bahwa radiasi smartphone menimbulkan ancaman penyakit seperti tumor otak, kangker, Alzheimer dan Parkinson. Tetapi hal itu masih menjadi perdebatan antara pakar keseharan lain, karena ketika di teliti hasil penelitian menunjukkan bahwa gelombang radiasi smarphone yang saat ini di pasaran masih tergolong aman.

Namun dengan demikian memerlukan tips bijak untuk menggunakan smartphone terutama saat telepon misalnya dengan menelepon tidak terlalu lama, mendekatkan smartphone pada telinga terlalu lama, menggunakan casing anti radiasi.

10. Ancaman cyberbullying

Cyberbullying adalah sebuah bentuk pelecehan atau bullying di dunia maya, biasanya hal ini terjadi melalui media jejaring sosial. 
Selain itu, priyatna mengungkapkan beberapa dampak negatif lainnya yaitu:

1. Anak yang terbiasa bermain game lebih dari 1 jam perhari atau rata-rata 7-10 jam perminggu, boleh jadi mereka akan mengorbankan jatah waktu untuk mengerjakan PR dan waktu untuk belajar yang berakibat negative untuk prestasi akademiknya di sekolah.

2. Ana menjadi malas untu melakukan aktivitas fisik yang berimbas pada kesehatan anak. Jika anak terus menerus menatap layer pada gawai, hal itu dapat menyebabkan masalah pada penglihatan (A. Priyatna, 2012).

\section{E. Bahaya Radiasi Gadget terhadap daya kembang anak}

Radiasi elektromagnetik terdiri dari gelombang elektrik dan energi magnetik dengan kecepatan cahaya. Semua energi elektromagnetik jatuh pada spectrum elektromagnetik, yang memiliki kisaran radiasi ELF (Extremly Low Frequency), sinar X, hingga sinar Gamma. Frekuensi yang dipancarkan oleh telepon genggam maupun tablet pada umumnya berada dikisaran 3 hingga $30 \mathrm{~Hz}$, yaitu termasuk gelombang radio (radiasi ELF). Walaupun tak sekuat sinar $\mathrm{X}$ yang merupakan jenis radiasi terionisasi dan mampu mengubah material genetik, radiasi yang dipancarkan gadget tetap memiliki pengaruh pada tubuh manusia (Jerry, 1999).

Bahaya radiasi gadget terhadap daya kembang anak adalah radiasi dari penggunan gadget yang tergolong gelombang RF, bukan merupakan gelombang yang sangat mematikan dan berbahaya. Tapi bukan berarti kemungkinan adanya efek samping tidak ada. Radiasi RF pada level tinggi serta dengan intensitas yang intensif dapat merusak jaringan tubuh. Radiasi RF memiliki kemampuan untuk memanaskan jaringan tubuh seperti oven microwave memanaskan makanan. Dan radiasi tersebut dapat merusak jaringan tubuh, karena tubuh kita tidak dilengkapi sistem ketahanan untuk 
mengantisipasi sejumlah panas berlebih akibat radiasi RF. Penelitian lain menunjukkan radiasi non-ionisasi (termasuk gelombang RF) menimbulkan efek jangka panjang.Penyakit yang berpotensi timbul karena radiasi gadget adalah kanker, tumor otak, alzheimer, parkinson, sakit kepala. Dibanding orang dewasa, anak-anak zaman sekarang sudah mengenal teknologi nirkabel sejak kecil sehingga waktu 'bersentuhan' dengan radiasi lebih panjang. Hal ini disebabkan karena di usia 12-15 tahun, anak mengalami proses bangkitnya akal, nalar dan kesadaran diri. Dalam masa ini terdapat energi dan kekuatan fisik serta tumbuh keinginan tahu dan keinginan cobacoba. Data memperlihatkan bahwa ketika radiasi dari gadget memasuki kepala, orang dewasa menyerapnya sebanyak 25\%, anak usia 12 tahun sebanyak 50\%, dan tertinggi pada anak usia 5 tahun, yaitu $75 \%$. Oleh karenanya, risiko radiasi ini akan lebih besar pada anak yang sudah 'akrab' dengan gadget di usia kurang dari 16 tahun.

\section{F. Strategi pendampingan orang tua dalam penggunaan gadget}

Sosok yang paling berpengaruh dalam mencegah maupun mengatasi dampak negatif dari gadget adalah orang tua. Maka orang tua memiliki peran besar dalam membimbing dan mencegah agar teknologi gadget tidak berdampak negatif bagi anak. Menurut Nanang Sahriana menjelaskan caracara yang harus dilakukan oleh orang tua ialah sebagai berikut:

1. Pilih sesuai usia

Dilihat dari tahapan perkembangan dan usia anak, pengenalan dan penggunaan gadget bisa dibagi ke beberapa tahap usia. Untuk anak usia di bawah 5 tahun, Pemberian gadget sebaiknya hanya seputar pengenalan warna, bentuk, dan suara. Artinya, jangan terlalu banyak memberikan kesempatan bermain gadget pada anak di bawah 5 tahun. Terlebih di usia ini, 
yang utama bukan gadget-nya, tapi fungsi atau peran orangtua. Pasalnya gadget hanya sebagai salah satu sarana untuk mengedukasi anak.

Ditinjau dari sisi neurofisiologis, otak anak berusia di bawah 5 tahun masih dalam taraf perkembangan. Perkembangan otak anak akan lebih optimal jika anak diberi rangsangan sensorik secara langsung. Misalnya, meraba benda, mendengar suara, berinteraksi dengan orang, dan sebagainya. Jika anak usia di bawah 5 tahun menggunakan gadget secara berkelanjutan, apalagi tidak didampingi orangtua, akibatnya anak hanya fokus pada gadget dan kurang berinteraksi dengan dunia luar.

Yang berikutnya, otak bagian depan adalah bagian yang berfungsi memberi perintah dan menggerakkan anggota tubuh lainnya. Di bagian otak belakang, ada yang namanya penggerak. Di bagian ini, terdapat hormon endorfin yang mengatur pusat kesenangan dan kenyamanan. Pada saat bermain gadget, anak akan merasakan kesenangan, sehingga memicu meningkatnya hormon endorfin. Kecanduan berhubungan dengan ini jika dilakukan dalam jangka waktu lama dan kontinyu. Akibatnya, ke depannya, anak akan mencari kesenangan dengan jalan bermain gadget, karena memang sudah terpola sejak awal perkembangannya.

Dari aspek interaksi sosial, perkembangan anak-anak usia di bawah 5 tahun sebaiknya memang lebih ke arah sensor-motorik. yaitu, anak harus bebas bergerak, berlari, meraih sesuatu, merasakan kasar-halus. Memang di gadget juga ada pengenalan warna atau games di mana orang melompat. Namun, kemampuan anak untuk berinteraksi secara langsung dengan objek nyata di dunia luar tidak diperoleh anak.

2. Batasi waktu

Anak usia di bawah 5 tahun, boleh-boleh saja diberi gadget. Tapi harus diperhatikan durasi pemakaiannya. Misalnya, boleh bermain tapi 
hanya setengah jam dan hanya pada saat senggang. Contohnya, kenalkan gadget seminggu sekali, misalnya hari Sabtu atau Minggu. Lewat dari itu, ia harus tetap berinteraksi dengan orang lain. Aplikasi yang boleh dibuka pun sebaiknya aplikasi yang lebih ke fitur pengenalan warna, bentuk, dan suara.

Sejalan pertambahan usia, ketika anak masuk usia pra remaja, orangtua bisa memberi kebebasan yang lebih, karena anak usia ini juga perlu gadget untuk fungsi jaringan sosial mereka. Di atas usia 5 tahun (mulai 6 tahun sampai usia 10 tahun) orangtua bisa memperbanyak waktu anak bergaul dengan gadget. Di usia ini, anak sudah harus menggali informasi dari lingkungan. Jadi, kalau tadinya cuma seminggu sekali selama setengah jam dengan supervisi dari orangtua, kini setiap Sabtu dan Minggu selama dua jam. Boleh main games atau browsing mencari informasi. Intinya, kalau orang tua sudah menerapkan kedisiplinan sedari awal, maka di usia pra remaja, anak akan bisa menggunakan gadget secara bertanggungjawab dan tidak kecanduan gadget.

3. Hindarkan kecanduan

Kasus kecanduan atau penyalahgunaan gadget biasanya terjadi karena orangtua tidak mengontrol penggunaannya saat anak masih kecil. Maka sampai remaja pun ia akan melakukan cara pembelajaran yang sama. Akan susah mengubah karena kebiasaan ini sudah terbentuk. Ini sebabnya, orang tua harus ketat menerapkan aturan ke anak, tanpa harus bersikap otoriter. Dan jangan lupa, orangtua harus menerapkan reward and punishment. Kalau ini berhasil dijalankan, maka anak akan bisa melakukannya secara bertanggungjawab dan terhindar dari kecanduan.

Ciri-ciri anak yang sudah kecanduan antara lain: (a) anak menghabiskan sebagian besar atau seluruh waktunya hanya untuk bermain 
dengan gadget. (b) anak mengabaikan/mengesampingkan kebutuhan lain hanya untuk bermian gadget. Misalnya lupa makan, lupa mandi. (c) anak mengabaikan teguran-teguran dari orang sekitar

4. Beradaptasi dengan zaman

Salah satu dampak positif gadget adalah akan membantu perkembangan fungsi adaptif seorang anak. Artinya kemampuan seseorang untuk bisa menyesuaikan diri dengan keadaan lingkungan sekitar dan perkembangan zaman. Jika perkembangan zaman sekarang muncul gadget, maka anak pun harus tahu cara menggunakannya. Artinya fungsi adaptif anak berkembang. seorang anak harus tahu fungsi gadget dan harus bisa menggunakannya karena salah satu fungsi adaptif manusia zaman sekarang adalah harus mampu mengikuti perkembangan teknologi. Sebaliknya, anak yang tidak bisa mengikuti perkembangan teknologi bisa dikatakan fungsi adaptifnya tidak berkembang secara normal. Namun, fungsi adaptif juga harus menyesuaikan dengan budaya dan tempat seseorang tinggal. Kalau anak tinggal di sebuah desa dimana gadget adalah barang langka, maka wajar kalau anak tidak tahu dan tidak kenal yang namanya gadget.

Sedangkan menurut Muhammad Nazir, sikap orang tua kepada anak mengenai gadget saat ini antara lain:

1. Pilih sesuai dengan usia anak

Jika anak masih di bawah 2 tahun cukup pengenalan gadget terlebih dahulu yaitu mengenai pengertian apa itu gadget selebihnya mengenai penggunaannya sebaiknya dibatasi. Pada usia anak dibawah 5 tahun cukup mengenalkan mengenai warna, bentuk, serta suara yang terdapat pada fitur atau aplikasi gadget tersebut. 
2. Selektif dalam memilihkan aplikasi permainan di dalam gadget Apabila anak memaksa untuk menggunakan gadget untuk bermain, pastikan aplikasinya sesuai dengan usia anak dan batasi aplikasinya, supaya anak tidak terlalu tertarik dengan permainan yang ada. Pilih aplikasi yang juga dapat mendukung kecerdasan anak, dan pola pikir anak.

3. Temani anak dalam bermain

Temani anak dalam bermain menggunakan gadget, arahkan penggunaannya dengan baik. Cobalah untuk mengajak anak bermain menggunakan media lain selain gadget, atau ajak anak bermain dengan teman sebayanya, supaya anak tidak terfokus dengan permainan gadgetnya. Orang tua juga harus menemani anaknya dalam penggunaan gadget dan mengenalkan hubungan dengan dunia nyata.

4. Batasi waktu bermain gadget anak

Batasi penggunaan gadet pada anak. Anak boleh saja menggunakan gadget tetapi waktunya dibatasi misalnya setengah jam, atau saat senggang atau saat hari sabtu atau minggu. Waktu di saat santai dan tugas belajarnya telah selesai.

5. Mengajak anak melakukan kegiatan positif

Ajak anak untuk melakukan kegiatan positif nisalnya setiap pagi olahraga, membantu membersihkan rmah, membaca buku, merapikan kamar, mengaji, mengikuti les Bahasa dan masih banyak lagi kegiatan positif yang bisa dilakukan untuk mencegah anak supaya tidak kecanduan bermain gadget. 


\section{PENUTUP}

\section{Simpulan}

Penggunaan gadget saat ini bukan hanya kalangan orang dewasa maupun remaja saja, anak-anak yang masih duduk di playgroup kini sudah tidak asing dengan yang namanya gadget. Orang tua pun akhirnya sudah bnyak yang memberikan gadget kepada anak. Tanpa disadari oleh orang tua, banyak anak yang sudah kecanduan gadget. Hal tersebut masih di anggap sepele oleh orang tua, sebab orang tua menganggap bahwa sekarang adalah era digital yaitu zaman memakai gadget.

Orang tua memberikan gadget kepada anak karena beberapa alasan, seperti menenangkan anak saat rewel, membuat anak mudah tidur atau makan, dan memberikan waktu luang bagi orang tua agar dapat melakukn pekerjaan rumah tangga atau bersantai. Satu hal yang sering dilupakan adalah efek negatif dari radiasi gadget dapat mempengaruhi kesehatan tubuh manusia, terutama bagi anak-anak. Alasan mengapa kebanyakan orang, terutama anak-anak, mengabaikan fakta ini karena kurangnya pengawasan dari orang tua atau pengasuh mereka.

Orang tua harus tegas atau tidak boleh memanjakan anaknya yang umurnya dibawah 6 tahun untuk menggunakan gadget. Karena lebih banyak dampak negatif yang timbul apabila seorang anak di bawah umur telah diberikan gadget. Salah satu dampak negatif penggunaan gadget pada anak antara lain: 1) menjadi pribadi tertutup, 2) kesehatan otak terganggu, 3) kesehatan mata terganggu, 4) kesehatan tangan terganggu, 5) gangguan tidur, 6) suka menyendiri, 7) perilaku kekerasan, 8) pudarnya kreativitas, 9) terpapar radiasi, dan 10) ancaman cyberbullying.

Sosok yang paling berpengaruh dalam mencegah maupun mengatasi dampak negatif dari gadget adalah orang tua. Maka orang tua memiliki peran 
besar dalam membimbing dan mencegah agar teknologi gadget tidak berdampak negatif bagi anak. Cara-cara yang harus dilakukan oleh orang tua ialah sebagai berikut: 1) pilih sesuai dengan usia anak, 2) Selektif dalam memilihkan aplikasi permainan di dalam gadget, 3) Temani anak dalam bermain, 4) Batasi waktu bermain gadget anak, dan 5) Mengajak anak melakukan kegiatan positif.

Maka orang tua harus berani mengubah dirinya sendiri, jika selama ini ada yang salah. Jika selama ini egois, selama ini mau menang sendiri terhadap anak, otoriter, itu harus berani diubah untuk kepentingan bersama. Jadi, ada saatnya orang tua menjadikan anak sebagai satu titik fokus terpenting untuk perkembangan dan masa depan anak itu sendiri. Sehingga masa pertumbuhan dan perkembangan anak lebih terarah dan menghasilkan psikologi anak yang baik pula. Seperti kata pepatah "buah jatuh tak pernah jauh dari pohonnya" anak yang tumbuh kembang yang baik berasal dari didikan dan pengawasan yang baik dari orangtuanya.

\section{DAFTAR PUSTAKA}

Andrianie, Prilya Shanty. (2010). Modul Deteksi Tumbuh Kembang Anak. Qinan:

Sukoharjo.

Baihaqi, M. \& M. Sugiarmin. (2006). Memahami dan Membantu Anak ADHD. Bandung: PT. Refika Aditama.

Brooks, Jane. (2011). The Process of Parenting. Yogyakarta: Pustaka Pelajar. Edisi ke-8

Hartoyo, Bambang. (2004). Konsep Dasar Pendidikan Anak Usia Dini, Materi Tutor dan Pengelola Pendidikan Anak Usia Dini, di BPPLSP Regional III, Jawa Tengah.

Hibana, Rahman. (2002). Konsep Dasar Pendidikan Anak Usia Dini. Yogyakarta: PGTKI Press. 
Iswidharmanjaya, Derry. (2014). Bila Si Kecil Bermain Gadget. Yogyakarta: Bisakimia.

Jerry B. (1999). Classical Electromagnetic Radiation. New York : State University of New York.

Jonathan,dkk. (2015). Perancangan Board Game Mengenai Bahaya Radiasi Gadget Terhadap Anak. Surabaya: Universitas Kristen Pertra Surabaya.

Nazir, Mohammad. (2003). Metode penelitian. Jakarta: Ghalia Indonesia.

Priyatna, A. (2012). Parenting di Dunia Digital. Jakarta: PT. Indeks.

Sahriana, Nanang. (2019). Pentingnya Peran Orang Tua Dalam Penggunaan Gadget Pada Anak Usia. Jurnal Smart PAUD 2(1).

Widiawati. (2014). Pengaruh Penggunaan Gadget Terhadap Daya Kembang Anak. Jakarta: Universitas Budi Luhur. 